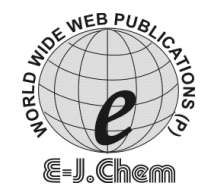

http://www.e-journals.net

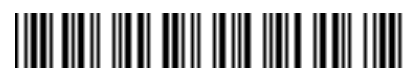

ISSN: 0973-4945; CODEN ECJHAO

E-Journal of Chemistry

Vol. 4, No. 3, pp. 390-396, July 2007

\title{
Analysis and Recommendation of Agriculture Use of Distillery Spentwash in Rampur District, India
}

\author{
SUSHEEL KUMAR SINDHU* AMIT SHARMA and SAIQA IKRAM ${ }^{\#}$ \\ Department of Chemistry, \\ S. S. V. (PG) College, HAPUR- 245101 (Ghaziabad), India. \\ "Department of Chemistry, Faculty of Natural Sciences, \\ Jamia Millia Islamia, New Delhi-110 025, India. \\ susheelsindhu@yahoo.co.in
}

Received 23 December 2006; Accepted 8 February 2007

\begin{abstract}
The potential value and the problems associated with the usage of spentwash in Rampur District were studied and also their environmental impacts were discussed. The studies revealed that, though at higher doses $\left(>250 \mathrm{~m}^{3} / \mathrm{ha}\right.$ ) spentwash application is found detrimental to crop growth and soil fertility, its use at lower doses $\left(125 \mathrm{~m}^{3} / \mathrm{ha}\right)$ remarkably improves germination, growth and yield of dryland crops. Further, it has been revealed that conjoint application of spentwash and organic amendments (farm yard manure, green leaf manure and bio-compost) is found suitable under dryland conditions. Large amounts of soluble salts have been found to be leached from calcareous and high $\mathrm{pH}$ sodic soils amended with spentwash. Notably, application of spentwash has resulted in leaching of high amounts of sodium from high $\mathrm{pH}$ sodic soils reflecting its potential in ameliorating these soils. However, exceptionally high loading of the leachate with organic and inorganic contaminants may pose potential risk for groundwater contamination.
\end{abstract}

Keywords: Spentwash, Acidification, Oxygen depletion, Aquatic Life, Rampur District.

\section{Introduction}

India is a major producer of sugar in the world, and sugar industry offers employment potential and contributes substantially to economic development. There are about 579 sugar 
mills and 285 distilleries in India. Apart from the sugar and alcohol, these factories generate many by-products and waste materials. For example, more than 5 million tones of solid waste (pressmud) are being produced from sugar industries. In addition, the industries also generate about 7.5 million tones of molasses and 45 million tones of bagasse as valuable by-products ${ }^{1,2}$.

The disposal of wastes from industrial sources is becoming a serious problem throughout the world. Alone in Rampur district, approximately 5 million $\mathrm{m}^{3}$ of distillery spentwash is discharged annually from 215 distilleries. The distillery spentwash is acidic $(\mathrm{pH}<4.0)$ and is generally characterized by high levels of biological oxygen demand and chemical oxygen demand and nutrient elements such as nitrogen and potassium. It is used as a source of plant nutrients and organic matter for various agricultural crops, particularly, under dryland conditions. However, indiscriminate disposal of this wastewater has resulted in adverse impact on soil and environmental health.

The spentwash is acidic ( $\mathrm{pH}$ 3.94-4.30) and loaded with organic and inorganic salts, resulting in high EC (30-45 dS/m). Being plant originated, the spentwash also contains considerable amounts of plant nutrients and organic matter. Nitrogen content in spentwash ranges from 1660 to $4200 \mathrm{mg} / \mathrm{L}$, phosphorus from 225 to $3038 \mathrm{mg} / \mathrm{L}$ and potassium from 9600 to $17475 \mathrm{mg} / \mathrm{L}$. Calcium, magnesium, sulphate and chloride are also present in appreciable amounts. Thus, it can effectively be used as a source of plant nutrients and as soil amendment. Recently, the presence of appreciable amounts of plant growth promoters viz., gibberellic acid and indole acetic acid have also been detected which further enhances the nutritient value of spentwash ${ }^{3-5}$. The high concentration of calcium $(2050-7000 \mathrm{mg} / \mathrm{L})$ in spentwash may have the potential in reclaiming the sodic soils similar to that of gypsum effect.

Though the spentwash generally does not contain any toxic metals, but is characterized by a high BOD and COD levels. Therefore, high BOD, COD and other organic compounds like phenols, lignin and oil and greases in spentwash are likely to deteriorate soil and environmental health. The unpleasant odour due to the presence of skatole, indole and other sulphur compounds, which are not effectively decomposed by yeast or methanogenic bacteria during distillation, is also an issue of public concern. The beneficial effect of spentwash on crop production is well documented ${ }^{6,7}$. However, little information is available on its usage as a soil amendment in dryland soils and its possible pollution potential. Therefore, this paper aims to examine the potential beneficial and detrimental effects of distillery spentwash application in dryland agriculture in Rampur district.

\section{Experimental}

\section{Effect of spentwash in seed hardening}

Seed hardening is a specific treatment given to seeds before sowing to withstand adverse soil moisture conditions. It is being recommended for better establishment of seeds in rain fed agriculture. The physiological and biochemical nature of the seed is modified due to seed hardening treatment mainly to resist drought at the time of sowing. Seed hardening is normally practiced with water and chemicals such as $\mathrm{KH}_{2} \mathrm{PO}_{4}(0.5 \%), \mathrm{KCl}(2 \%), \mathrm{ZnSO}_{4}$ $(0.01 \%)$, etc. The efficacy of spentwash in seed hardening of ragi (Eluesine coracana), groundnut (Arachis hypogaea), gingelly (Sesamum indicum), sorghum (Sorghum bicolour) and green gram (Vigna radiata) at different concentrations were compared with existing seed hardening treatment. The seeds were soaked with 10 or $20 \%$ solution of spentwash at a seed:solution ratio of $1: 1$ for $16 \mathrm{~h}$ (ragi and sorghum), $12 \mathrm{~h}$ (gingelly), $6 \mathrm{~h}$ (groundnut) and $3 \mathrm{~h}$ (green gram) and air-dried to initial moisture content (8-10\%). The seeds were sown in 
$2.5 \mathrm{~kg}$ soil in the sintex pots. Germination, root and shoot length, biomass production and vigour index were measured.

\section{Pollution potential of spentwash}

Soil leaching experiments were conducted to examine the mobility and transport of salts and the possible groundwater contamination with spentwash application ${ }^{8,9}$. The soil columns (cylindrical PVC tubes with an internal diameter of $7.0 \mathrm{~cm}$ ) were constructed containing layers of soil with different bulk densities viz., 1.4 (subsurface) and 1.3 (surface) $\mathrm{mg} / \mathrm{m}_{3}$. The spentwash was applied at a rate equivalent to $0,25,125,250$ and $500 \mathrm{~m}^{3} / \mathrm{ha}$ with and without organic amendments viz., farmyard manure (FYM @ 12.5 t/ha), green leaf manure (GLM, daincha-Sesbania aculeata @ $6.25 \mathrm{t} / \mathrm{ha}$ ) and biocompost (BC@3 t/ha). Ten days after incubation leaching was carried out with water and the leachates collected and analyzed for $\mathrm{pH}, \mathrm{EC}, \mathrm{Na}^{+}, \mathrm{Ca}^{2+}, \mathrm{Mg}^{2+}, \mathrm{Cl}^{-}$and $\mathrm{SO}_{4}^{2-}$ contents. Four weeks after leaching 10-15 seeds of ragi were sown in all columns and the germination and the vigour index examined. After ten days the columns were dismantled and soils from each layer removed and analyzed for $\mathrm{pH}, \mathrm{EC}, \mathrm{Na}^{+}, \mathrm{Ca}^{2+}, \mathrm{Mg}^{2+}, \mathrm{Cl}^{-}$and $\mathrm{SO}_{4}^{2-}$ contents.

\section{Bio-toxicity of spentwash}

The bio-toxicity study on the effect of groundwater contamination of spentwash on aquatic life was investigated on fingerlings of a fresh water fish species viz., Cyprinuscarpio var. communis ${ }^{10}$. The fingerlings were acclimatized to laboratory conditions for about 3 weeks before experimentation. The spentwash was added at different concentration ranging from 0.1 to $10 \%$ (v/v). A static bioassay technique was employed considering its simplicity and accuracy. The survival/mortality of fingerlings was recorded and the LC50 (Lethal concentration estimated to produce mortality in $50 \%$ of the test population over a period of $24 \mathrm{~h}$ ) calculated ${ }^{11}$.

\section{Effect of spentwash on selected soil properties, seed germination and crop yields}

The effect of spentwash at rates equivalent to single application of $0,25,50,125,250$ and 500 $\mathrm{m}^{3} / \mathrm{ha}$ with and without organic amendments viz., FYM (12.5 t/ha), GLM (daincha@6.25 t/ha) and $\mathrm{BC}(3 \mathrm{t} / \mathrm{ha})$ on selected soil properties $(\mathrm{EC}, \mathrm{pH}, \mathrm{N}, \mathrm{P}, \mathrm{K}$, organic carbon, and exchangeable sodium percentage, ESP) and on production of selected dryland crops (ragi, groundnut, gingelly, sorghum, rice and green gram) were examined. The soils used in the pot and field experiments were either vertisol (a deep moderately well drained, calcareous clay soil belongings to fine montmorillonite verticustropepts, Entic chromustert in USDA classification), or an alfisol (a deep well drained, loam soil belonging to fine loamy textured Typic rhodustalfs) or a sodic soil (with a high $\mathrm{pH}>9.8$ ). Cotton (Gossypium vitifolium), pulses (e.g. green gram), millets (e.g. Pennisetum glaucum) and small millets (ragi) are grown as main crops in these dry tracts. These soils are generally low in organic carbon and plant available nutrients.

\section{Results and Discussion}

\section{Effect of spentwash in seed hardening}

It has been consistently shown that the seed hardening with the spentwash at a concentration of 10 and $20 \%(\mathrm{v} / \mathrm{v})$ markedly improved the germination of ragi groundnut, gingelly, sorghum and green gram by $16,30,28,27$, and $28 \%$, respectively, over the control. Similarly, such seed treatment with spentwash was also found to improve the root length $(420 \%)$, plant height $(500 \%)$, biomass production $(161 \%)$ and vigour index $(315 \%)$. Marked increase in $\mathrm{N}(11-13 \%), \mathrm{P}(17-20 \%)$ and $\mathrm{K}(16-27 \%)$ contents of crops was also recorded 
due to spentwash treatment over the control. This effect was more pronounced in green gram than other crops. The seed hardening with spentwash at higher rate $(20 \%)$ was found more effective than the lower rate $(10 \%)$ and other chemical treatments in improving the growth parameters. These effects could be ascribed to the nutrients and the growth promoters like gibberellic acid and indole acetic acid present in the spentwash.

\section{Bio-toxicity of spentwash}

The results revealed that with increasing concentration of spentwash, the salt loading in test solution increased several fold $(\mathrm{EC}>4.8 \mathrm{dS} / \mathrm{m})$. It resulted acidification $(\mathrm{pH}<6.4)$ and depletion of dissolved oxygen $(\mathrm{DO}<2.25 \mathrm{mg} / \mathrm{L}$ ) content of the test solution. A high rate of mortality of fingerlings was observed with the increase in the concentration of spentwash. The estimated $\mathrm{LC}_{50}$ for distillery spentwash was found to be $0.5 \%$. The destruction of aquatic life in water bodies like river Ganga and Gomti due to indiscriminate disposal of spentwash was reported in India ${ }^{12}$.

\section{Effect of spentwash on selected soil properties}

The effect of spentwash on selected properties of sodic soil in the presence and absence of organic amendments is presented in Table- 1 . The spentwash application significantly reduced the $\mathrm{pH}$ of sodic soil. Increase in the rate of spentwash application resulted a notable decrease in the $\mathrm{pH}$ of soils and such effect was more pronounced in the presence of organic amendments ${ }^{13}$. The decrease in soil $\mathrm{pH}$ may be attributed to the acidic nature of the spentwash and the release of organic acids during the decomposition. The electrical conductivity of soil increased markedly due to accumulation of salts from spentwash. The concentration of plant available nutrients $\left(\mathrm{KMnO}_{4}-\mathrm{N}, \mathrm{NaHCO}_{3}-\mathrm{P}\right.$, and $\mathrm{NH}_{4} \mathrm{OAc}-\mathrm{K}$ ) in soil increased substantially. Application of organic amendments appeared to have an additive effect in improving the efficacy of the spentwash and followed BC > GLM > FYM. Significant increase in organic carbon content of soils was also observed which could be ascribed to the addition of organic matter through spentwash application. Similar effect was also observed in vertisol and alfisol ${ }^{5}$. Marked reduction in ESP of sodic soil was also observed due to spentwash application (Table-1). The exchangeable Ca present in the spentwash might have replaced the $\mathrm{Na}+$ from the exchange sites in the soil and eventually reduced the ESP. Data (not presented) on exchangeable $\mathrm{Ca}^{2+}$ and $\mathrm{Na}^{+}$in soil further confirmed these observations.

Table 1. Effect of spentwash application on selected characteristics of sodic soil.

\begin{tabular}{llllll}
\hline Soil characteristic & Contol & SW & SW+FYM & SW+GLM & SW+BC \\
\hline $\mathrm{pH}$ & 9.24 & 7.73 & 7.25 & 7.52 & 7.43 \\
$\mathrm{EC}(\mathrm{dS} / \mathrm{m})$ & 0.84 & 11.0 & 10.2 & 10.5 & 12.4 \\
Organic Carbon , \% & 0.26 & 0.67 & 0.71 & 0.70 & 0.71 \\
$\mathrm{KMnO}_{4}-\mathrm{N}, \mathrm{Kg}, \mathrm{ha}$, & 185 & 235 & 251 & 258 & 264 \\
$\mathrm{NaHCO}_{3}-\mathrm{P}, \mathrm{kg} / \mathrm{ha}$, & 16.7 & 24.6 & 27.0 & 28.5 & 30.20 \\
$\mathrm{NH}_{4} \mathrm{OAc}-\mathrm{K} \mathrm{kg} / \mathrm{ha}$ & 265 & 2725 & 2850 & 2850 & 3560 \\
ESP & 27.0 & 21.00 & 15.6 & 17.4 & 14.7 \\
\hline
\end{tabular}

$\mathrm{SW}=$ Spentwash $\left(500 \mathrm{~m}^{3} / \mathrm{ha}\right) ; \mathrm{FYM}=$ Farmyard manure $(12.5 \mathrm{t} / \mathrm{ha})$;

GLM=Green leaf manure ( $6.25 \mathrm{t} / \mathrm{ha}) ; \mathrm{C}=$ Biocompost $(3 \mathrm{t} / \mathrm{ha})$

In the case of vertisol and alfisol, Murugaragavan ${ }^{5}$ observed increase in SAR and ESP due to application of spentwash. However, these values (SAR < 3.62; ESP <4.8) were well below the threshold levels, suggesting even at higher rate the spentwash application is unlikely to cause any sodicity problem in these soils. Although initial enhancement in enzymes (phosphatase, dehydrogenase and urease) and microbial (actinomycetes, yeast and 
bacteria) activities was evident in soil amended with the spentwash, no marked effect was observed at the end of 60 days incubation ${ }^{5}$. The results of pot and field experiments showed marked improvement in soil fertility as evident from the increase in available N, P, and K. From this study, it could be inferred that the spentwash at $25 \mathrm{~m}^{3} /$ ha may have potential in improving the productivity of vertisol without affecting the soil health. Whereas, in alfisol still lower dose may be required. However, long term field experiments are needed to confirm these results.

\section{Effect of spentwash on seed germination and crop yields}

Data from pot experiment demonstrated that the spentwash $>50 \mathrm{~m}^{3} / \mathrm{ha}$ was found detrimental for the germination and establishment of green gram in vertisol, whereas, in alfisol even at a rate of $25 \mathrm{~m}^{3} / \mathrm{ha}$, the spentwash was found to inhibit the germination and growth of green gram. However, in vertisol the germination, growth, nutrients contents and yield of green gram were significantly improved with spentwash application at $25 \mathrm{~m}^{3} / \mathrm{ha}$. Differential crops response to spentwash application was also evident. For example, in a field experiment with rice (Oryza sativa) grown on sodic soil (Table-2).

Table 2. Effect of spentwash with and without organic amendments on grain yield of rice $(\mathrm{kg} / \mathrm{ha})(\mathrm{s})$

\begin{tabular}{ccccc}
\hline \multirow{2}{*}{ Treatments } & \multicolumn{4}{c}{ Levels of spentwash application, $\mathrm{m}^{3} /$ ha } \\
\cline { 2 - 5 } & 0 & 125 & 250 & 500 \\
\hline Control & 1270 & 2150 & 945 & 710 \\
FYM & 1915 & 2366 & 1110 & 854 \\
GLM & 1960 & 2575 & 118 & 826 \\
BC & 2238 & 2480 & 1210 & 752 \\
& Manure $(\mathrm{M})$ & Spentwash (S) & M X S & \\
CD (p=0.05) & 66.5 & 50.1 & 112.2 & \\
\hline
\end{tabular}

\section{Effect of spentwash on salt transport and movement}

Data from the soil leaching experiments showed that large amounts of soluble cations were found leached from soils amended with the spentwash (Tables 3 and 4). Increase in the rate of spentwash application had markedly enhanced the leaching of cations. Calcium was the dominant cation leached from calcareous vertisol (Table-3), whereas, greater amount of $\mathrm{Na}^{+}$ was found leached from high $\mathrm{pH}$ sodic soil (Table-4) reflecting the exchange reactions of spentwash- $-\mathrm{Ca}^{2+}$ with $\mathrm{Na}^{+}$on the soil exchange sites. This suggests that the spentwash may have potential in ameliorating the sodic soils.

Table 3. Effect of spentwash and organic amendments on total amount (mg) of cations and anions leached from calcareous vertisol

\begin{tabular}{llllll}
\hline Ions & Control & SW & SW+FYM & SW+GLM & SW+BC \\
\hline $\mathrm{Ca}^{2+}$ & 910 & 3007 & 3511 & 3840 & 4283 \\
$\mathrm{Mg}^{2+}$ & 132 & 351 & 315 & 224 & 479 \\
$\mathrm{Na}^{+}$ & 36 & 126 & 140 & 151 & 215 \\
$\mathrm{~K}^{+}$ & 5 & 11 & 9 & 17 & 17 \\
$\mathrm{Cl}^{-}$ & 495 & 1739 & 1887 & 1984 & 2025 \\
$\mathrm{SO}_{4}{ }^{2-}$ & 1351 & 3493 & 2329 & 1827 & 3502 \\
\hline
\end{tabular}

$\mathrm{SW}=$ Spentwash $\left(500 \mathrm{~m}^{3} / \mathrm{ha}\right) ; \mathrm{FYM}=$ Farmyard manure $(12.5 \mathrm{t} / \mathrm{ha})$;

GLM=Green leaf manure $(6.25 \mathrm{t} / \mathrm{ha}) ; \mathrm{C}=$ Biocompost $(3 \mathrm{t} / \mathrm{ha})$ 
Table 4. Effect of spentwash and organic amendments on total amount (mg) of cations and anions leached from sodic soil.

\begin{tabular}{llllll}
\hline Cations/ anions & Control & SW & SW+FYM & SW+GLM & SW+BC \\
\hline $\mathrm{Ca}^{2+}$ & 574 & 1523 & 1569 & 2205 & 1915 \\
$\mathrm{Mg}^{2+}$ & 203 & 1403 & 1872 & 1365 & 1263 \\
$\mathrm{Na}^{+}$ & 1026 & 2044 & 1869 & 2135 & 2412 \\
$\mathrm{~K}^{+}$ & 5 & 28 & 28 & 27 & 25 \\
$\mathrm{Cl}^{-}$ & 1372 & 2856 & 3381 & 2699 & 2268 \\
$\mathrm{SO}_{4}{ }^{2-}$ & 1050 & 1953 & 3206 & 3395 & 4291 \\
\hline
\end{tabular}

$\mathrm{SW}=$ Spentwash $\left(500 \mathrm{~m}^{3} / \mathrm{ha}\right) ; \mathrm{FYM}=$ Farmyard manure $(12.5 \mathrm{t} / \mathrm{ha})$;

GLM=Green leaf manure (6.25 t/ha); C=Biocompost $(3 \mathrm{t} / \mathrm{ha})$

Application of organic amendments was found to enhance the leaching of cations from the spentwash amended soils, mainly, by improving the hydraulic conductivity and other physical conditions of soils. Application of spentwash both in the presence and absence of organics resulted in large amounts of $\mathrm{Cl}^{-}$and $\mathrm{SO}_{4}{ }^{2-}$ leached from soils. Chloride and $\mathrm{SO}_{4}{ }^{2-}$ leaching was relatively greater from sodic soil than calcareous vertisol. While the potential salinity of leachate from sodic soil was less than vertisol, the SAR was found higher with sodic soil than vertisol.

The leachates from both vertisol and sodic soil amended with spentwash had exceptionally high organic loading as indicated by BOD and COD (Table-5). This demonstrates the adverse effect of the spentwash application on groundwater contamination. Though not of similar magnitude, field observation of the open well waters around spentwash applied fields also had revealed deterioration of water quality due to high BOD, COD and excessive salt content.

Table 5. BOD and COD of leachate collected from vertisol and sodic soil.

\begin{tabular}{lllll}
\hline \multirow{2}{*}{\multicolumn{1}{c}{ Treatment }} & \multicolumn{2}{c}{ Vertisol } & \multicolumn{2}{c}{ Sodic soil } \\
\cline { 2 - 5 } & $\begin{array}{l}\text { BOD, } \\
\mathrm{mg} / \mathrm{L}\end{array}$ & $\begin{array}{l}\mathrm{COD}, \\
\mathrm{mg} / \mathrm{L}\end{array}$ & $\begin{array}{l}\text { BOD, } \\
\mathrm{mg} / \mathrm{L}\end{array}$ & $\begin{array}{c}\mathrm{COD}, \\
\mathrm{mg} / \mathrm{L}\end{array}$ \\
\hline Control & 153 & 137 & 124 & 194 \\
Spentwash, $\left(125 \mathrm{~m}^{3} / \mathrm{ha},\right)$ & 8331 & 24136 & 7695 & 21200 \\
Spentwash, $\left(125 \mathrm{~m}^{3} / \mathrm{ha}+\mathrm{FYM}\right)$ & 6921 & 15227 & 5368 & 11090 \\
Spentwash, $\left(125 \mathrm{~m}^{3} / \mathrm{ha}+\mathrm{GLM}\right)$ & 10342 & 16887 & 8352 & 12589 \\
Spentwash, $\left(125 \mathrm{~m}^{3} / \mathrm{ha}+\mathrm{BC}\right)$ & 12356 & 18043 & 9588 & 15421 \\
$\mathrm{CD}(\mathrm{p}=0.05)$ & 453 & 182 & 431 & 1104 \\
\hline
\end{tabular}

Even after seven leaching events soils had large accumulation of salts from spentwash application both in the presence and absence of any organic amendments. The accumulation of cations followed: $\mathrm{K}^{+}>\mathrm{Ca}^{2+}>\mathrm{Na}^{+}>\mathrm{Mg}^{2+}$ in vertisol, and $\mathrm{K}^{+}>$ $\mathrm{Ca}^{2+}=\mathrm{Na}^{+}>\mathrm{Mg}^{2+}$ in sodic soil. While large amount of $\mathrm{Cl}^{-}$was found accumulated, only traces of $\mathrm{SO}_{4}{ }^{2-}$ were measured in both soils. Even after seven leaching events, the establishment of ragi, as measured by germination and vigour index, was markedly suppressed due to the application of large amounts of spentwash. However, its combined application with organic amendments particularly GLM and FYM improved the germination and the vigour index. 


\section{Conclusions}

Distillery spentwash is acidic and contains high levels of soluble salts. Among the plant nutrients, $\mathrm{K}$ is found in higher amounts followed by $\mathrm{N}$ and $\mathrm{P}$. The presence of $\mathrm{Ca}$ in considerable amounts makes the spentwash a potential amendment for reclaiming sodic soils. The beneficial effect of spentwash on crop production was exerted only at lower rate of application. The presence of appreciable amounts of plant growth promoters viz., gibberellic acid and indole acetic acid adds additional value to the spentwash. Although the spentwash application increased the soil salinity induced by accumulation of salts, it had markedly improved the fertility status of dry land soils. Enhancement in the activities of enzymes and microbes was also evident in soils amended with the spentwash. Seed hardening with $20 \%$ spentwash was found very effective in improving the germination, and growth parameters in certain dry land crops. However, exceptionally high organic loading is likely to diminish the nutrient potential of the spentwash. The contamination of surface and ground waters, destruction of aquatic life and excessive accumulation of salts in soils pose serious threat to sustenance of soil and environmental health. Technologies based on scientific experimentation are needed for effectively utilizing this valuable resource in agriculture without any environmental hazards.

\section{References}

1. Allen C J, Mackay M J, Aylward J H and Campbell J A, Keating and Wilson, Ed., CAB,International, Wallingford, UK, 1997, 267-285.

2. Azbar N, Bayram A, Filibeli A, Muezzinoglu A, Sengul F and Ozer A, Crit. Rev. Environ. Sci. Tech. 2004, 34, 209.

3. Rajukkannu K and Manickam T S, Proceedings of the Sixth National Symposium on Environment, Tamil Nadu Agricultural University, Coimbatore, India, 1997, 286-290.

4. Valliappan K, Recycling of distillery spentwash and ecofriendly effective reclamation technology for soils, Ph.D. Thesis, Tamil Nadu Agricultural University, Coimbatore, India, 1998.

5. Murugaragavan R, Distillery spentwash on crop production in dryland soils. M. Sc. Thesis, Tamil Nadu Agricultural University, Coimbatore, India, 2002.

6. Joshi H C, Pathak H, Choudhary A and Kalra N, Fertilizer News 1996, 41, 41.

7. Ramana S, Biswas A K and Singh A B , Bioresour. Tech., 2002, 84, 295.

8. Kumar V, Wati L, Nigam P, Banat I M, Yadav B S, Singh D and Marchant, R, Process biochem., 1998, 33, 75.

9. Evaluation of Soil Washing Technology, Cambridge, MA, U.S., Environmental Protection Agency, Cincinnati, OH, Office of Research and Development, Risk Reduction Engineering Laboratory, June 1991.

10. Rao T S and Viraraghavan T, Treatment of Distillery Wastewater (spentwash)Indian Experience, $40^{\text {th }}$ PIWC, 1985, 53-58.

11. Nagarajan K and Shasikumar R, J. Ecotoxicol. Environ. Monitor. 2002, 12, 233.

12. Joshi H C, Proceedings of the National Seminar on Management of Fisheries in Inland Open Water Systems of India, Barrackpore, West Bengal,1988, 23-30.

13. Ali khan M A and Kaushik P, Third International Conference on Plants and Environmental Pollution (ICPRP-3), Lucknow, 2005, p 505. 


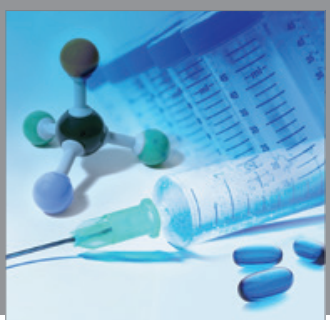

International Journal of

Medicinal Chemistry

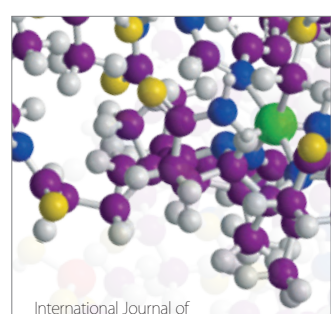

Carbohydrate Chemistry

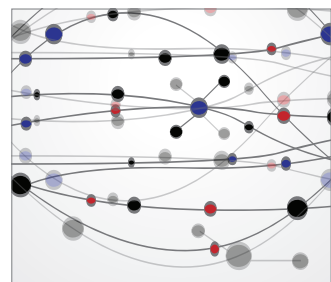

The Scientific World Journal
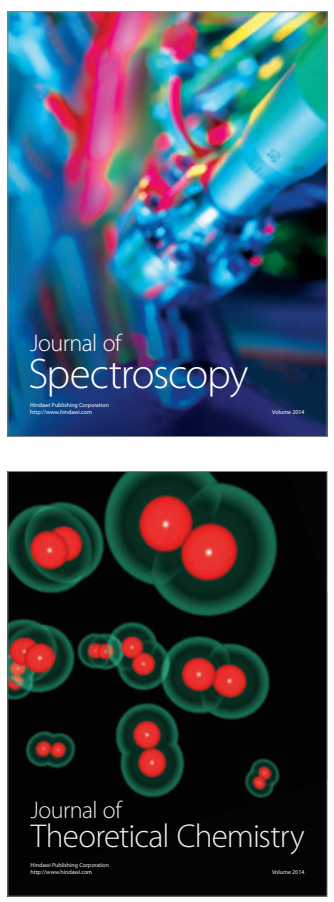
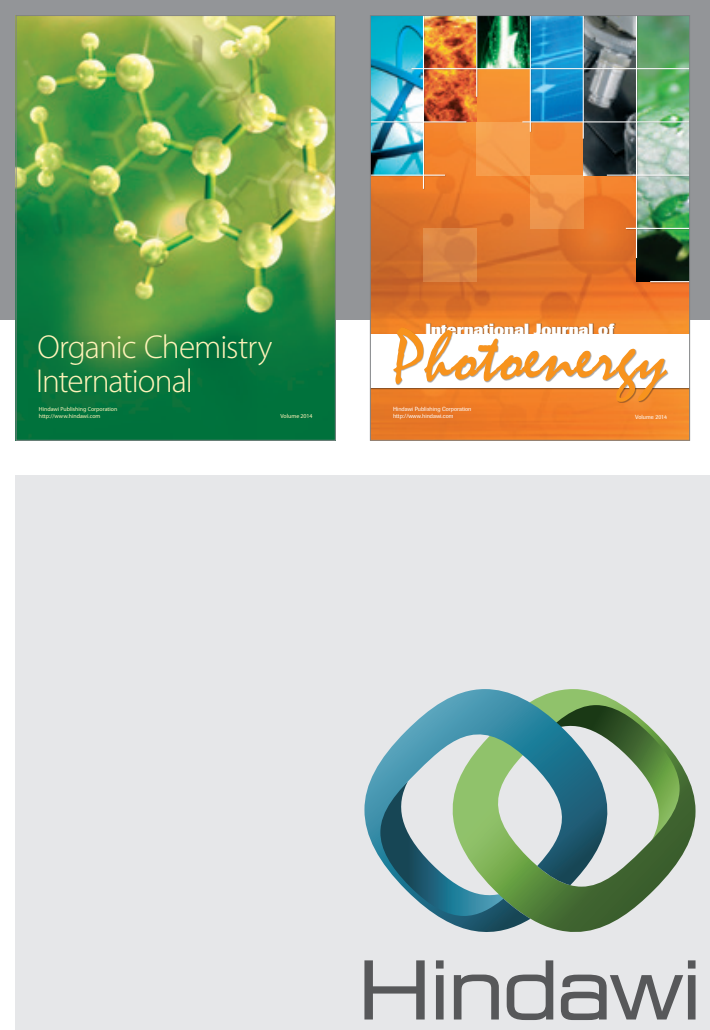

Submit your manuscripts at

http://www.hindawi.com
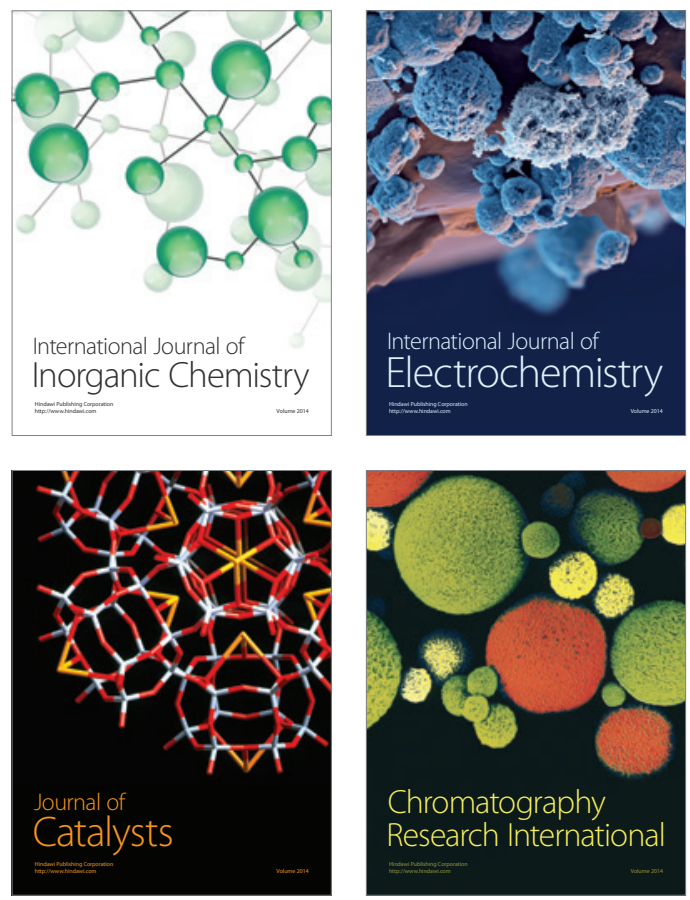
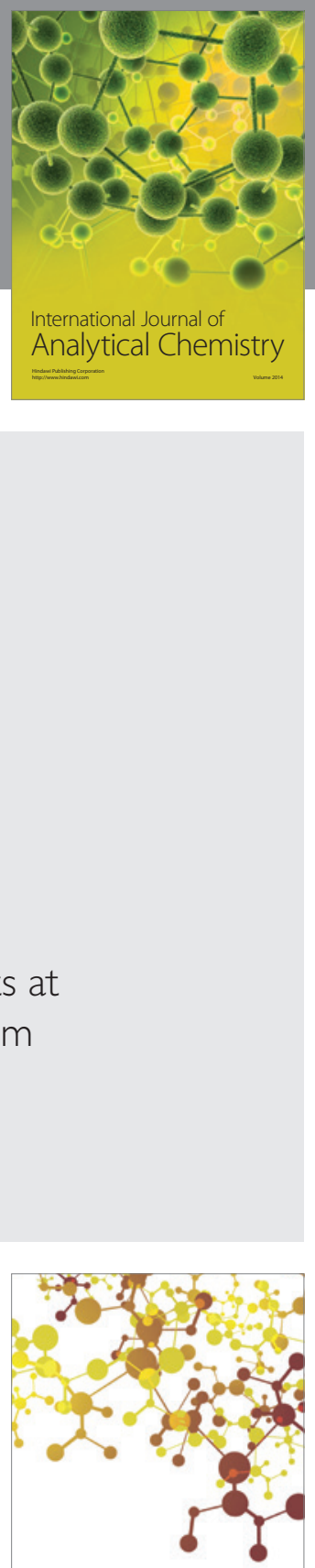

Journal of

Applied Chemistry
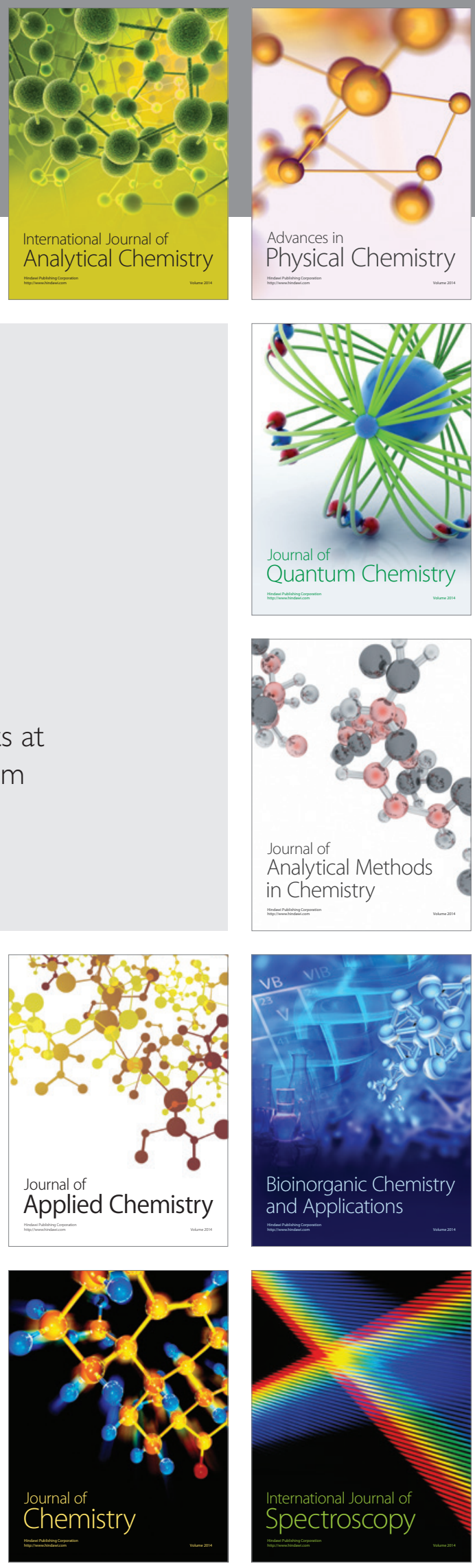